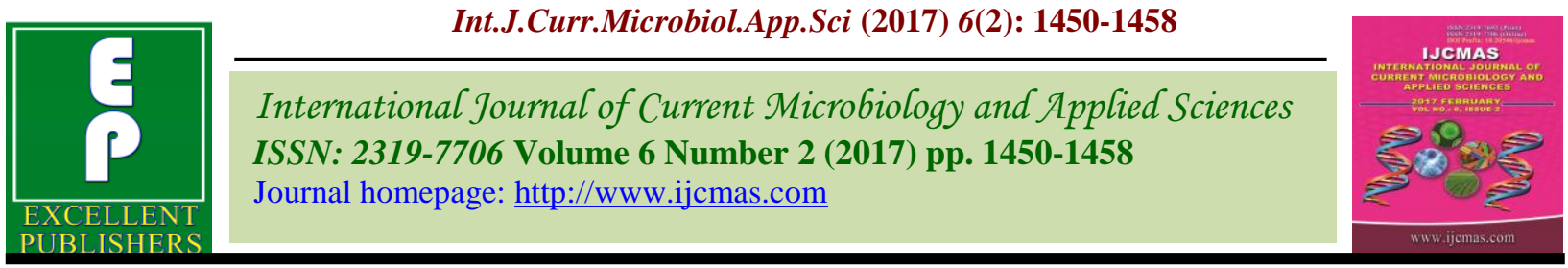

Original Research Article

http://dx.doi.org/10.20546/ijcmas.2017.602.162

\title{
Socio Economics Variability of the Livestock Owners Lakhimpur (Kheri) (U.P), India
}

\author{
Aditya Kumar Kannojiya ${ }^{1}$ and Subodh Kumar ${ }^{2 *}$ \\ ${ }^{1}$ Department of Animal Husbandry U.P, India \\ ${ }^{2}$ ILFC Collage of Veterinary Science and A.H., N.D.U.A.T Kumarganj \\ Fizabad U.P (224229), India \\ *Corresponding author
}

\begin{tabular}{|c|c|}
\hline & A B S T R A C T \\
\hline $\begin{array}{l}\text { Ke y w o r d s } \\
\text { Milk Production } \\
\text { Practices, } \\
\text { Farmers, Animals, } \\
\text { Live stock Owners. }\end{array}$ & \multirow{3}{*}{$\begin{array}{l}\text { The indigenous technical knowledge (ITK) regarding animal husbandry is } \\
\text { considered as old as domestication of various livestock species. Unfortunately, } \\
\text { these practices which are in vogue throughout the rural India are little documented } \\
\text { and there is danger of extinction of this knowledge. Thus it is become imperative } \\
\text { to collect and document these practices. A semi structured interview schedule was } \\
\text { used for the data collection from } 10 \text { traditional healers and } 120 \text { livestock owners. } \\
\text { It was found that improved farm implements aid not only in saving labour but also } \\
\text { increases working efficiency at farm. The majority of the respondents }(56.67 \%) \\
\text { were found belonging to medium material possession category while } 18.33 \\
\text { percent and } 25.00 \text { percent of respondents were of low and high material } \\
\text { possession category, respectively. }\end{array}$} \\
\hline Article Info & \\
\hline $\begin{array}{l}\text { Accepted: } \\
\text { 24 January } 2017 \\
\text { Available Online: } \\
\text { 10 February } 2017\end{array}$ & \\
\hline
\end{tabular}

\section{Introduction}

India's livestock sector is one of the largest in the world. According to $18^{\text {th }}$ livestock census (2007) there are 199 million cattle, 105 million buffaloes, 72 million sheep, 141 million goats, 11 million pigs and 649 million poultry birds in India, contributing 56.7 percent of world's buffaloes, 12.5 percent cattle, 20.4 percent small ruminants, 2.4 percent camel, 1.4 percent equine, 1.5 percent pigs and 3.1 percent poultry (Anonymous, 2011). In 2010-11, livestock generated output worth rupees 2075 billion (at 2004-05 prices) which constitutes 4 percent of the India's total GDP and 26 percent of the agricultural GDP. The word 'indigenous' means native born origination or produced naturally in a country or in specified area and the word knowledge means "assured belief practical skill, that is known, learning enlightenment" (Reijntjes et $a l .$, 1993). The indigenous knowledge is also often taken to be synonymous with traditional knowledge (Richard, 1979). Also, the term indigenous is often interchangeably used with terms like traditional or local (Yadav, 1998). Traditional includes recent and future innovations provided and carried out by farmers but it does not mean "Absolute" i.e. neither absolute good nor bad (Pareira, 1993). However, Johnson (1993) feels that societies change through time constantly adopting new practices and technologies, making it difficult to define just how much and what kind of 
change would effects the labelling of a practice as "Traditional". The indigenous technical knowledge is a systematic body of knowledge and practice acquired by the local people through accumulation of their own and their ancestral experiences, formal and informal experiments and intimate understanding of the environment in a given culture while dealing with situation and problems in various aspect of life. The indigenous knowledge is dynamic. It changes through creativity and innovativeness as well as through contact with other knowledge system, as it remains in continuous interaction with local knowledge and the changing socioeconomic and ecological conditions of the regions.

\section{Materials and Methods}

This refers to the position and respect a respondent enjoys in his/her own limited society as determined by caste, religion, gender, marital status, family type, family size, type of house and material possession. The maximum tribal population regarding in district Lakhimpur (Kheri). So, Lakhimpur (Kheri) district will be selected purposely. Out of total seven tehsils in the district, Palia tehsil were selected purposely due to the existence of maximum number of tribal families in the distrct. The Palia Tehsil having a single Palia block. So, palia block of Palia Tehsil were selected purposely. An extansive list of villages in Palia Block was prepared and ten villages were selected randomly. Twelve livestock owner from each of the selected villages were identified randomly. Thus a total of 120 livestock owner were finally identified as a sample size. For inculcating the Indigenous therapeutic knowledge of traditional practices one healer from each of selected villages was identified. Thus ten healers were selected randomly. A personal interview schedule was developed keeping in view the objectives and variables of study. Background information of the study area was obtained through personal observation, consultation with official and available reports. Before the actual data collection, several visits were made to build rapport with the respondents of the selected villages and officials. Quantitative and qualitative data were collected through observation, interaction dialogue, detailed discussion with key informants, aged persons, housewives and traditional healers. Total about 65 days were spend in 10 selected villages for data collection during the period of January 2014 to I ${ }^{\text {st }}$ week of March 2014. The data were collected, compiled, tabulated and analysed using frequency, simple percentage mean and standard deviation. Thus researcher will exploit all possible opportunities to collect the relevant primary and secondary information for descriptive analysis.

\section{Results and Discussion}

\section{Age}

The indicates that majority of respondents $(55.83 \%)$ were found under middle age group (41-59 years) followed by 22.50 percent and 21.67 percent were in old age group (more than 59 years) and young age group (less than 41 years), respectively (Table 1).

\section{Gender}

The study indicates that majority of respondents $(98.33 \%)$ were male while 1.67 percent were female (Table 2).

\section{Caste category}

All respondents (100\%) were found to be of Schedule tribe category. It might because of the Government regulation which banned buying and selling of the land to other caste of the people in the study area. 


\section{Education}

Education is one of the important factors which accelerate growth of farm business. The standard of family education moulds the farmer's response to improved technology and helps in shaping a enterprise to earn more. The table 3 indicates that majority of respondents $(33.33 \%)$ were illiterate category, followed by primary $(26.67 \%)$, can read and write $(24.17 \%)$, middle $(9.17 \%)$, can read only $(5.83 \%)$ and intermediate $(0.83 \%)$.

\section{Occupation}

\section{Primary occupation}

The table 4 indicates that primary occupation of majority of the respondents $(78.33 \%)$ was agriculture, followed by labourer $(15.00 \%)$, animal husbandry (5.84\%) and business $(0.83 \%)$.

\section{Subsidiary occupation}

Table 5 indicates that subsidiary occupation of majority of respondents (41.67\%) was animal husbandry, followed by business $(35 \%)$, labourer (20\%) and agriculture $(3.33 \%)$.

\section{Type of family}

The table 6 indicates the dominance of joint families in the research area as $(63.33 \%)$ were as about one third (36.67\%) were found belonging to nuclear families.

\section{Size of family}

The size of the family is one of the important factors influencing labour availability in a crop and livestock enterprises. Table 7 shows that majority of the respondents (76.67\%) were found belonging to medium size family (5-20 members) followed by 15.83 percent were belonged to large size family (more than
20 members) whereas very few $(7.50 \%)$ had small size family of less than five members. The largest family found in the study area had 85 members.

\section{Type of house}

The table 8 indicates that majority of the respondents $(57.50 \%)$ had the hut type residence followed by kuccha house (41.67\%) and pacca house $(0.83 \%)$ respectively.

\section{Land holding}

Land is one of the important scarce resources. It is also considered as one of the socioeconomic indicator in agricultural sector and rural development. The production processes at farm and volume of livestock enterprises are mainly based on the farm size.

The table 9 shows that majority of the respondents 49.17 percent were found to be small farmers (up to 2.5 acre) followed by 25.83 percent were found to marginal farmers (2.5 to 5 acre) while, 25.00 percent respondents were found belonged to large farmers category of more than 5 acre land.

\section{Herd size}

The productivity of milch animals varies considerably depending upon the type of breeds maintained. Local descript or nondescript cows and buffaloes were reared by the farmers singly or in combinations. In order to determine the strength of milch animals perform as a unit, cattle equivalent score were computed based on comparative assigned values.

Table 10 indicates that the majority of the respondents $(70.00 \%)$ were found belonging to medium category whereas, 5.00 percent and 25.00 percent were under small and large categories, respectively. 


\section{Milk production and disposal behaviour}

\section{Per day milk yield}

The productivity of milch animal is attributed to their genetic potentials, feeding and management practices. Milk yield per household per annum depends upon the number of milch animal in lactation during the year. It is further determined by a kind of breed owned, access to feed and fodder and management practices adopted for milch stock. Table 11 points out that very few respondents in $(14.17 \%)$ were found belonging to low category ( 7 lit. / day). However, majority of the respondents $(70 \%)$ percent were belonging to medium milk producing category (7-17 lit. / day) while 15.83 percent respondents were found belonging to high milk producing category (>17 lit. / day).

\section{Marketed milk}

Farmers usually sale quantity of milk, depending upon its availability to meet out the routine expenditure in the family. How much of the total quantity of the milk available is marketed depend on how much is retained for family consumption. It varies markedly by selected livestock owners, frequency distribution of the respondents is presented in the table 12 . The majority of the respondents $(67.50 \%)$ were found belonging to medium milk selling category (5-10 lit. /day) while 20 percent and 12.50 percent respondents were found under low and high milk selling categories, respectively.

\section{Milk consumption}

It is commonly observed that farmers rear animals in order to ensure the availability of milk for their family consumption and marketing. Milk consumed by the family members show partly the availability of milk per household and the nutritional status of the family. In the dietary pattern of rural folks, milk consumption assumes significant importance. In order to examine the milk consumption pattern frequency distribution of farmers is shown in the table 13. The majority of the respondents $(75.00 \%)$ were found belonging to medium milk consumption category while 4.17 percent and 20.83 percent of respondents were of high and low milk consumption categories, respectively.

\section{Total annual income}

Table 14 indicates that majority of the respondents $(65.83 \%)$ reported their family income ranged between Rs. 24250 to $34750 /-$ per year whereas, about 19.17 percent and 15 percent respondents had their earning even less than Rs. 24250/- per year and more than Rs. 34750/- per year and thus found under low and high categories, respectively.

\section{Social participation}

Study revealed that majority of the respondents $(55 \%)$ were not associated with any social organisation followed by 35.83 percent were member of one organisation whereas 9.17 percent were member of more than one organisation (Table 15).

\section{Extension agency contact}

It was found that more than half of the respondents had medium extension agency contact followed by high (40.84\%) and low extension agency contact (5.83\%), respectively (Table 16).

\section{Mass media exposure}

The distribution of the respondents according to their mass media shows that as many as 51.67 percent of them had a medium level of mass media exposure, followed by high level of mass media exposure $(35.00 \%)$ and low level of mass media exposure (13.33\%), respectively (Table 17). 
Table.1 Distribution of the respondents as per their age $(\mathrm{N}=120)$

\begin{tabular}{lcc}
\hline Categories (years) & f & \% \\
\hline Young $(<41)$ & 26 & 21.67 \\
Middle $(41-59)$ & 67 & 55.83 \\
Old $(>59)$ & 27 & 22.50 \\
\hline & Total= 120 & $\mathbf{1 0 0}$ \\
\hline
\end{tabular}

Mean $=50.33$, S.D. $=9.17$

Table.2 Distribution of the respondents as per their gender $(\mathrm{N}=120)$

\begin{tabular}{lcc}
\hline Categories & f & \% \\
\hline Male & 118 & 98.33 \\
Female & 2 & 1.67 \\
\hline & Total $=\mathbf{1 2 0}$ & $\mathbf{1 0 0}$ \\
\hline
\end{tabular}

Table.3 Distribution of the respondents as per their education $(\mathrm{N}=120)$

\begin{tabular}{lcr}
\hline Categories & f & \% \\
\hline Illiterate & 40 & 33.33 \\
Can read only & 07 & 5.83 \\
Can read and write & 29 & 24.17 \\
Primary & 32 & 26.67 \\
Middle & 11 & 9.17 \\
Intermediate & 01 & 0.83 \\
\hline
\end{tabular}

Table.4 Distribution of the respondents as per their Primary occupation $(\mathrm{N}=120)$

\begin{tabular}{lrr}
\hline Categories & f & \% \\
\hline Agriculture & 94 & 78.33 \\
Animal Husbandry & 7 & 5.84 \\
Business & 1 & 0.83 \\
Labourer & 18 & 15.00 \\
\hline & Total= 120 & $\mathbf{1 0 0}$ \\
\hline
\end{tabular}

Table.5 Distribution of the respondents as per their subsidiary occupation $(\mathrm{N}=120)$

\begin{tabular}{lcc}
\hline Variable & f & \% \\
\hline Agricultural & 4 & 3.33 \\
Animal Husbandry & 50 & 41.67 \\
Business & 42 & 35.00 \\
Labourer & 24 & 20.00 \\
\hline & Total= 120 & $\mathbf{1 0 0}$ \\
\hline
\end{tabular}


Table.6 Distribution of the respondents as per their type of family ( $N=120)$

\begin{tabular}{lcc}
\hline Categories & f & \% \\
\hline Nuclear & 44 & 36.67 \\
Joint & 76 & 63.33 \\
\hline & Total $=\mathbf{1 2 0}$ & $\mathbf{1 0 0}$ \\
\hline
\end{tabular}

Table.7 Distribution of the respondents as per their size of family ( $\mathrm{N}=120)$

\begin{tabular}{lcc}
\hline Categories (member) & f & \% \\
\hline Small $(<5)$ & 9 & 7.50 \\
Medium (5-20) & 92 & 76.67 \\
Large $(>20)$ & 19 & 15.83 \\
\hline & Total $=\mathbf{1 2 0}$ & $\mathbf{1 0 0}$ \\
\hline Mean $=12.85$, S D $=7.65$
\end{tabular}

Mean $=12.85$, S.D. $=7.65$

Table.8 Distribution of the respondents as per their type of house $(\mathrm{N}=120)$

\begin{tabular}{lcc}
\hline Categories & f & \% \\
\hline Hut & 69 & 57.50 \\
Kuccha & 50 & 41.67 \\
Pucca & 1 & 0.83 \\
\hline & & $\mathbf{1 0 0}$ \\
\hline
\end{tabular}

Table.9 Distribution of the respondents as per their land holding $(\mathrm{N}=120)$

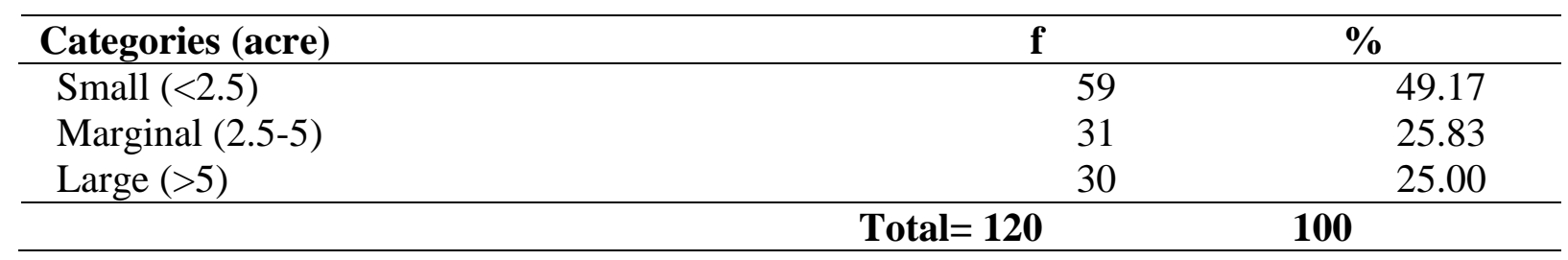

Table.10 Distribution of the respondents as per their herd size $(\mathrm{N}=120)$

\begin{tabular}{lrr}
\hline Categories (cattle equivalent score) & f & \% \\
\hline Small $(<6)$ & 6 & 5.00 \\
Medium (6-14) & 84 & 70.00 \\
Large $(>14)$ & 30 & 25.00 \\
\hline & Total= 120 & $\mathbf{1 0 0}$ \\
\hline
\end{tabular}

Mean $=10.78$, S.D. $=4.44$ 
Table.11 Distribution of the respondents as per milk yield $(\mathrm{N}=120)$

\begin{tabular}{lcc}
\hline Categories (lit. / day) & f & \% \\
\hline Low $(<7)$ & 17 & 14.17 \\
Medium (7-17) & 84 & 70.00 \\
High $(>17)$ & 19 & 15.83 \\
\hline
\end{tabular}

Mean $=12.25$, S.D. $=5.18$

Table.12 Distribution of the respondents as per marketed milk $(\mathrm{N}=120)$

\begin{tabular}{lcc}
\hline Categories (lit. / day) & f & \% \\
\hline Low (<5) & 24 & 20.00 \\
Medium (5-10) & 81 & 67.50 \\
High (>10) & 15 & 12.50 \\
\hline
\end{tabular}

Mean $=11.23$, S.D. $=6.11$

Table.13 Average per day milk consumption (lit.) (N=120)

\begin{tabular}{lrr}
\hline Categories (lit. / day) & f & \% \\
\hline Low (<3) & 25 & 20.83 \\
Medium (3-7) & 90 & 75.00 \\
High $(>7)$ & 5 & 4.17 \\
\hline
\end{tabular}

Mean $=5.38$, S.D. $=2.13$

Table.14 Distribution of the respondents as per annual income $(\mathrm{N}=120)$

\begin{tabular}{lcc}
\hline Categories (Rs. / annum) & f & \% \\
\hline Low $(<24250)$ & 23 & 19.17 \\
Medium $(24250-34750)$ & 79 & 65.83 \\
High $(>34750)$ & 18 & 15.00 \\
\hline & Total= 120 & $\mathbf{1 0 0}$ \\
\hline
\end{tabular}

Mean $=29500$, S.D. $=5250.21$

Table.15 Distribution of the respondents as per social participation $(\mathrm{N}=120)$

\begin{tabular}{lcc}
\hline Categories & f & \% \\
\hline No social participation & 66 & 55.00 \\
Member of one organisation & 43 & 35.83 \\
Member of more than one organisation & 11 & 9.17 \\
\hline & Total= 120 & $\mathbf{1 0 0}$ \\
\hline
\end{tabular}


Table.16 Distribution of the respondents as per extension agency contact $(\mathrm{N}=120)$

\begin{tabular}{lcc}
\hline Categories (Score) & f & \% \\
\hline Low $(<3)$ & 7 & 5.83 \\
Medium $(3-7)$ & 64 & 53.33 \\
High $(>7)$ & 49 & 40.84 \\
\hline & Total= $\mathbf{1 2 0}$ & $\mathbf{1 0 0}$ \\
\hline
\end{tabular}

Mean= 5.48, S.D. $=2.02$

Table.17 Distribution of the respondents as per mass media exposure $(\mathrm{N}=120)$

\begin{tabular}{lcc}
\hline Categories (Score) & f & \% \\
\hline Low $(<3)$ & 16 & 13.33 \\
Medium (3-7) & 62 & 51.67 \\
High $(>7)$ & 42 & 35.00 \\
\hline & Total= 120 & $\mathbf{1 0 0}$ \\
\hline
\end{tabular}

Mean $=5.40$, S.D. $=2.35$

Table.18 Informal information source of utilization $(\mathrm{N}=120)$

\begin{tabular}{lcc}
\hline Categories (Score) & f & \% \\
\hline Low $(<9)$ & 18 & 15.00 \\
Medium (9-13) & 83 & 69.17 \\
High $(>13)$ & 19 & 15.83 \\
\hline & Total= 120 & $\mathbf{1 0 0}$ \\
\hline
\end{tabular}

Mean $=11.09$, S.D. $=2.52$

Table.19 Distribution of the respondents as per material possession $(\mathrm{N}=120)$

\begin{tabular}{lcc}
\hline Categories (Score) & f & \% \\
\hline Low $(<9)$ & 22 & 18.33 \\
Medium (9-19) & 68 & 56.67 \\
High $(>19)$ & 30 & 25.00 \\
\hline & Total= 120 & $\mathbf{1 0 0}$ \\
\hline
\end{tabular}

Mean $=14.64$, S.D. $=5.70$

\section{Informal information source utilization}

Study manifested that as many as 69.17 percent of the respondents comes under medium category whereas almost equal number of respondents were found belonging to low and high categories (Table 18).

\section{Material possession}

Material possession is one of the important indicators of the socio-economic status of rural people. Improved farm implements aid not only in saving labour but also increases working efficiency at farm. Table 19 indicates that the majority of the respondents (56.67\%) 
were found belonging to medium material possession category while 18.33 percent and 25.00 percent of respondents were of low and high material possession category, respectively.

In conclusion, as the young generation of the tribes had shown less interest in use of ITKs and the traditional practices are decaying with time facture. So, there is need to formulate extension strategies to motivate the younger generation to continue and modify the existing traditional practices.

\section{References}

Anonymous. 2011. Report of the working group on Animal Husbandry and Dairying 12th five year plan.pp.2.

Balakrishnan, V. 2009. Ethnoveterinary studies among farmers in Dindigul District of Tamil Nadu, India, Global J Pharmacol., 3(1): 15-23.

Basant, R. 1990. Documentation of indigenous practices in Gujrat agriculture. A note: In proceedings of the international workshop on sustainability through farmers' Improvement in Technology Generation and diffusion. Feburary 8, Indian Society of Agronomy, New Delhi.

Dohare, R.S. 1996. A study on indigenous technical knowledge in animal husbandry in Mathura district of U.P., Ph.D. Thesis, Division of Extension Education, IVRI, Izatnagar.

Dwivedi, S.K. 1998. Overview of ethonoveterinary practices in India. ICAR short summer course entitled "Techniques for scientific validation and evaluation of ethonoveterinary practices". 3-12 August, Division of Medicine, IVRI, Izatnagar, pp, 1-5.

Kumar, A., Pandey, V.C. and Tiwari, D.D. 2012. Documentation and determination of consensus about phytotherapeutic veterinary practices among the Tharu tribal community of Uttar Pradesh, India, Trop. Anim. Health Prod., 44: 863-872.

\section{How to cite this article:}

Aditya Kumar Kannojiya and Subodh Kumar. 2017. Socio Economics Variability of the Livestock Owners Lakhimpur (Kheri) (U.P). Int.J.Curr.Microbiol.App.Sci. 6(2): 1450-1458. doi: http://dx.doi.org/10.20546/ijcmas.2017.602.162 